\title{
Detection of diabetic foveal edema with biomicroscopy, fluorescein angiography and optical coherence tomography
}

\author{
Detecção do edema foveal diabético com biomicroscopia, \\ angiografia fluoresceínica e tomografia de coerência óptica
}

Rosana Zacarias Hannouche ${ }^{1}$ Marcos Pereira Ávila ${ }^{2}$
Trabalho realizado no Departamento de Oftalmologia da Universidade Federal de Goiás - UFG - Goiânia (GO) Brasil.

Pós-graduanda e voluntária do CEROF da Universidade Federal de Goiás - UFG - Goiânia (GO) - Brasil.

2 Professor Doutor e Chefe do CEROF da UFG - Goiânia (GO) - Brasil.

Endereço para correspondência: Rosana Zacarias Hannouche. Av. T-8, 171 - Goiânia (GO) CEP 74210-270

E-mail: hannoucherosana@ig.com.br

Recebido para publicação em 06.10.2007

Última versão recebida em 18.05.2008

Aprovação em 15.08.2008

Nota Editorial: Depois de concluída a análise do artigo sob sigilo editorial e com a anuência do Dr. João Carlos Miranda Gonçalves sobre a divulgação de seu nome como revisor, agradecemos sua participação neste processo.

\section{ABSTRACT}

To describe different techniques for the detection of diabetic foveal edema. A retrospective review of the detection of diabetic foveal edema. Noncontact lens biomicroscopy is relatively insensitive in mild foveal thickening apparent on optical coherence tomography. Optical coherence tomography measurements can detect early retinal damage in diabetic retinopathy patients.

Keywords: Fovea centralis; Tomography, optical coherence/methods; Retina/pathology; Diabetic, retinopathy; Visual acuity

\section{INTRODUCTION}

Diabetic retinopathy remains one of the main causes of blindness even in developed countries ${ }^{(1-3)}$ and is also a common cause of visual impairment and legal blindness ${ }^{(1,4)}$. Abnormal fluid accumulation within the retina and an increase in retinal thickness usually result from the breakdown of the blood-retinal barrier ${ }^{(1,3)}$.

The standard clinical method to determine the presence of diabetic macular edema (DME) is the subjective detection of macular thickening by various methods, using slit-lamp fundus biomicroscopy, such as the 78diopter noncontact or contact lens, indirect funduscopy, fluorescein angiography and fundus stereophotography. However, these methods are subjective and do not provide quantitative results.

Early detection of diabetic retinopathy (DR) is particularly important for patients with diabetes mellitus (DM), because advanced DR is more refractory to treatment. Previous studies have shown retinal thickening due to DR and morphological changes of the retina, even in the early stages of the disease $^{(2)}$.

The various methods used to evaluate macular thickening are relatively insensitive both to small changes in retinal thickness and in those cases in which visual acuity has not been affected yet ${ }^{(5)}$.

Optical coherence tomography (OCT) is a relatively new technique for high resolution cross-sectional imaging of the retina ${ }^{(6-7)}$. Additionally, since it is a noninvasive and noncontact procedure, without any iatrogenic features, OCT has been widely employed in the diagnosis of retinal diseases ${ }^{(8)}$.

With such an objective and accurate technique, it is possible to not only detect small changes in thickness, but also to determine the practical implications in the follow-up and efficacy of this treatment in our patients ${ }^{(1,9)}$. 
Thus, the aim of this paper is to present a review of the different propedeutic methods used to diagnose diabetic foveal edema.

\section{DISCUSSION}

\section{Different techniques for the detection of diabetic foveal edema}

Diabetic retinopathy is responsible for a significant degree of visual loss and legal blindness in diabetic patients.

The pathogenesis of diabetic macular edema has not been completely understood. It begins with the intracytoplasmic swelling of the Müller cells due to ischemia, thereby causing a cytotoxic edema ${ }^{(10)}$. This condition progresses to a vasogenic edema with a subsequent release of permeable substances, such as prostaglandins, and vascular endothelial growth factor from the ischemic retina ${ }^{(11)}$.

The main procedure (gold standard) to determine the presence of diabetic macular edema is a subjective analysis performed by slit-lamp fundus biomicroscopy with the 78-D noncontact lens ${ }^{(12)}$. Although Goldmann contact lens biomicroscopy was the clinical examination technique used in the ETDRS ${ }^{(13)}$, and is considered more sensitive than 78-D for detecting DME, examination with noncontact lens is more common in clinical practice. Some factors contribute to this result, such as the lack of observers with experience, patient compliance, adequate pupil dilatation, opaque media and the extension of the retinal edema.

Detecting diabetic macular edema with a slit lamp is subjective and can be difficult in the early stages of the disease ${ }^{(14)}$.

Excellent correlation was observed between OCT and slit-lamp biomicroscopy, with a 78-diopter noncontact lens examination, for the absence or presence of foveal edema, when OCT thickness is normal $(<200 \mu \mathrm{m})$ or moderately to severely increased $(>300 \mu \mathrm{m})$. It does not reflect the severity and the extent of the edema and the retinal layer involved in the thickening ${ }^{(12)}$.

Strom et al. show that there is a high level of correlation between fundus stereophotography and OCT, for the detection and location of retinal thickening. The first has the advantage of presenting good lateral resolution, while with OCT this is only possible through several scans. However, OCT is capable of detecting earlier signs of macular edema and structural modification ${ }^{(4)}$.

Early detection of DR and DME can substantially reduce the risk of visual impairment and blindness caused by diabetes $^{(14)}$.

Fluorescein angiography (FA) is one of the most efficient methods to identify areas of vascular leakage in retinal and functional studies. FA has been able to show early edema in $21 \%$ to $42 \%$ of diabetic adults who had results that were considered negative for retinopathy with other methods ${ }^{(14)}$. However, there is a significant correlation between OCT and fluorescein angiography features in diabetic macular edema
(Figure 1). Nevertheless, this evaluation is qualitative and subjective, so small changes may not be detected and correlated to visual acuity ${ }^{(15)}$. FA is an invasive diagnostic test that carries a limited but real risk of an anaphylactic reaction to sodium fluorescein and FA causes discomfort and sometimes nausea or vomiting to patients undergoing the procedure ${ }^{(14)}$.

Many types of optical imaging instruments, such as the retinal thickness analyzer (RTA) and optical coherence tomography (OCT), have been used to detect early diabetic damage ${ }^{(16-17)}$. Several studies have shown that OCT and the retinal thickness analyzer can quantify the retinal edema in these cases with greater accuracy ${ }^{(2)}$. OCT is more sensitive to small changes in retinal thickness than slit-lamp biomicroscopy $^{(5)}$. OCT-3, which became commercially available in 2002 , offers increased imaging speed and better axial $(<10 \mu \mathrm{m})$ view, when compared to previous versions of the instrument. It should also be noticed that a shorter scanning time and the consequent absence of movement by the patient, in addition to more refined algorithms, result in better image quality, in spite of being a high-cost procedure.

The images are obtained via six radial scans, centered on the fovea. The cross-sectional images were analyzed with the OCT-3 software, with the strongest borders of each tomography and supposing they were located on the internal vitreous-retinal face and on the external face of the retinal pigmented epithelium-choriocapillaris zone.

The thickness is measured between the two faces. The foveal thickness is usually defined as the mean thickness at the $1000 \mu \mathrm{m}$ diameter in the ETDRS layout, while the central foveal thickness is defined at the point of intersection of the six radial scans. This analysis protocol operates with six radial line scans or four macular thickness scans. The algorithm calculates, separately, the retinal thickness and combines the results in order to build the circular maps. Two maps are included in the analysis results.

One of them presents the retinal thickness through a color scale, and the other shows the thickening in each area, in micrometers $(\mu \mathrm{m})$. Each map consists of three concentric circles, and the two external ones are divided into sectors.

Numerical information is also obtained, and includes the center, which represents the average thickness $(\mu \mathrm{m})$, the standard deviation for the central point and the total volume of the retinal map, in millimeters $(\mathrm{mm})$. The map with pseudocolors presents an intuitive and efficient method to compare the retinal thickness with the observation made with slitlamp fundus biomicroscopy (Figure 2).

For the analysis of each eye, six consecutive OCT scans are usually made, with equal angular spacing and a radial pattern centered on the fovea. Each one of the six tomographies is oriented along the line that crosses the central fovea and contains 100 equally spaced axial profiles (A-scan).

Therefore, measurements of retinal thickness were made on a total of 600 points along these six intersected lines, and six lines were located through the central fovea. Each of the A-scans was run at $70 \mu \mathrm{m}$ from the nearest one. 


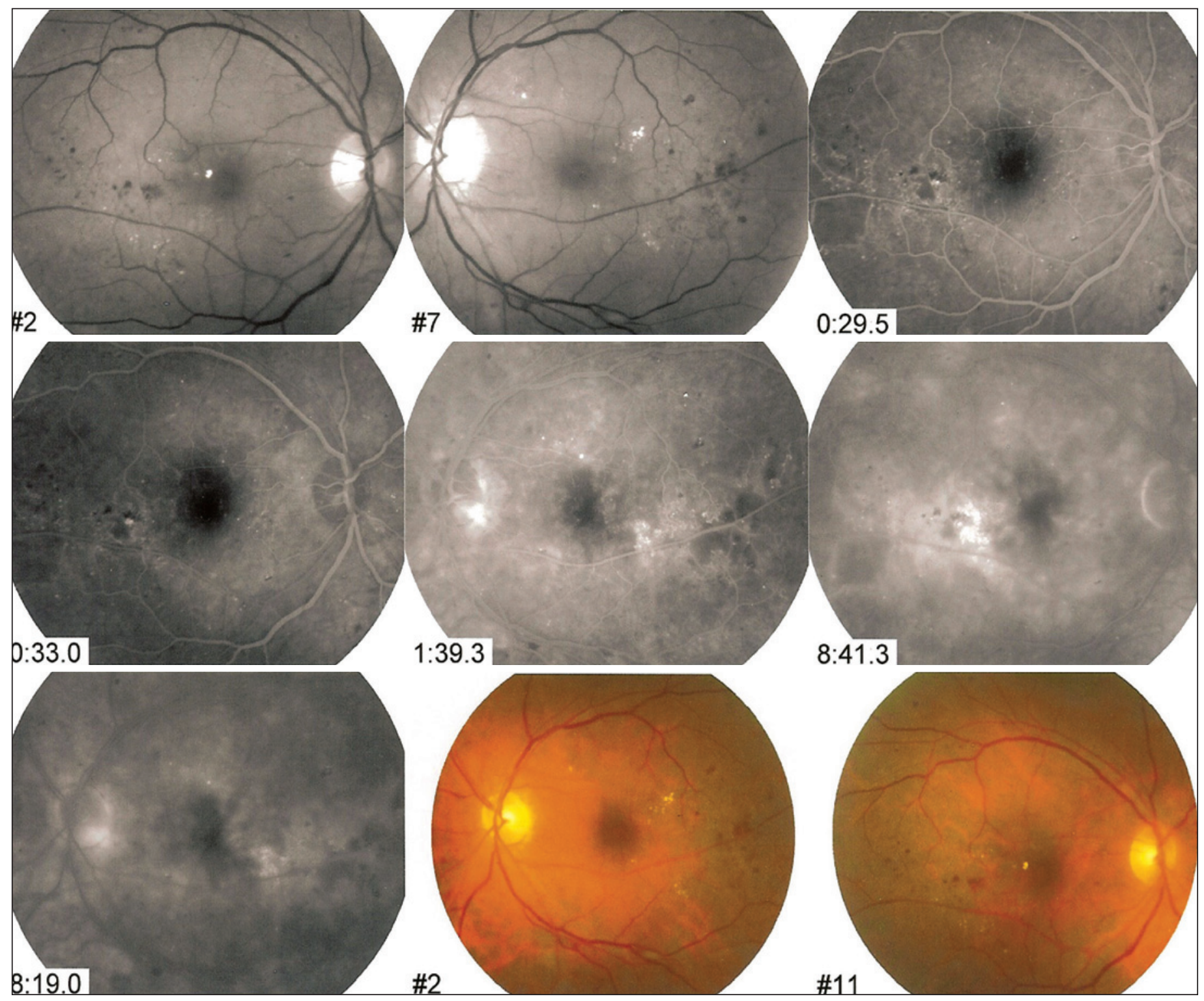

Figure 1 - Fluorescein angiography (FA) of the patient with diabetic macular edema

OCT, also called "optical biopsy", is an imaging technique that produces high-resolution cross-sectional images of the retina, and it offers a structural and quantitative analysis of diabetic macular edema.

OCT measures retinal thickness by considering the distance between the vitreoretinal interface and the anterior surface of the retinal pigmented epithelium (RPE) - choriocapillaris region. Retinal swelling is seen as increased retinal thickness with reduced intraretinal reflectivity and expanded areas of lower reflectivity. The algorithms detect changes in reflexibility, resulting in an accurate measurement of the retinal thickness. Hussain et al. ${ }^{(18)}$, point out the positive correlation between the mean macular thickness and visual acuity in diabetic patients with non-proliferative retinopathy ${ }^{(19)}$.
Previous studies show that there no difference between mean foveal thickness between male and female patients. Additionally, no correlation was found between a decrease in macular thickness and the normal aging process.

\section{CONCLUSIONS}

In conclusion, the analysis of diabetic macular edema by means of OCT provides information that may be useful to disclose the pathogenesis of the edema, to diagnose and optimize early treatment, when necessary, thereby reducing visual loss.

Further research is necessary to investigate whether diabetic patients with subclinical thickening present a greater probability of developing diabetic retinopathy. 


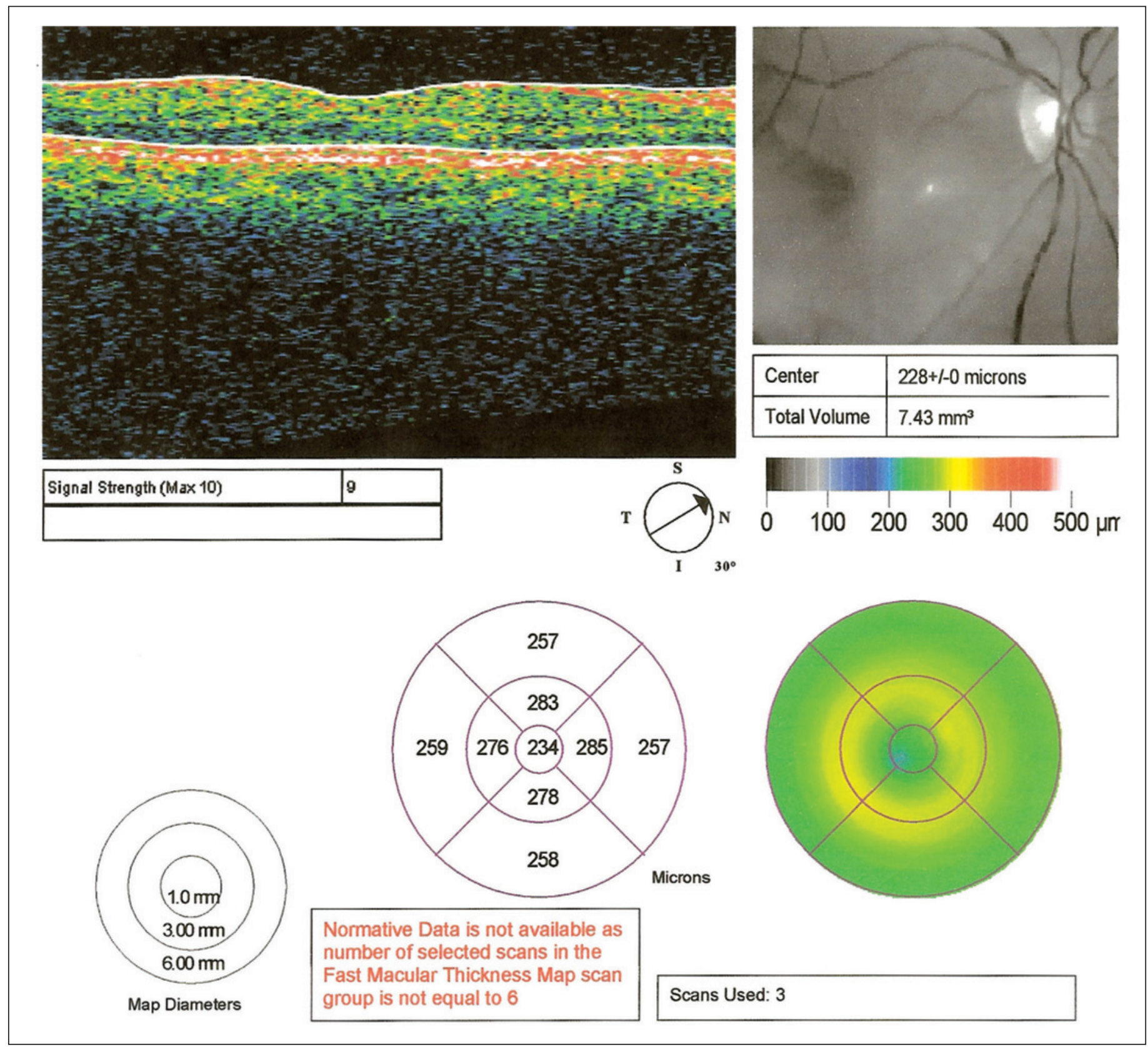

Figure 2 - Optical coherence tomography (OCT) shows diabetic macular edema

\section{RESUMO}

Descrever diferentes técnicas para detecção do edema foveal diabético. Uma revisão da detecção do edema foveal diabético. Biomicroscopia com lente de não contato é relativamente insensível em edema leve aparente na tomografia de coerência óptica. Tomografia de coerência óptica pode detectar precocemente o dano retiniano inicial em pacientes com retinopatia diabética.

Descritores: Fóvea central; Tomografia de coerência óptica/métodos; Retina/patologia; Retinopatia diabética; Acuidade visual

\section{REFERENCES}

1. Chan A, Duker JS, Ko TH, Fujimoto JG, Schuman JS. Normal macular thickness measurements in healthy eyes using Stratus optical coherence tomography. Arch Ophthalmol. 2006;124(2):193-8.

2. Sugimoto M, Sasoh M, Ido M, Wakitani Y, Takahashi C, Uji Y. Detection of early diabetic change with optical coherence tomography in type 2 Diabetes Mellitus patients with without retinopathy. Ophthalmologica. 2005;219(6): 379-85.

3. Abujamra S, Ávila M, Barsante C, Farah ME, Gonçalves JO, Lavinsky J, et al. Retina e vítreo - clínica e cirurgia. São Paulo: Roca; 2000.

4. Strom C, Sander B, Larsen N, Larsen M, Lund-Andersen H. Diabetic macular edema assessed with optical coherence tomography and stereo fundus photography. Invest Ophthalmol Vis Sci. 2002;43(1):241-5. 
5. Sanchez-Tocino H, Alvarez-Vidal A, Maldonado M, Moreno-Montanes J, Garcia-Layana A. Retinal thickness study with optical coherence tomography in patients with diabetes. Invest Ophthalmol Vis Sci. 2002;43(5):1588-94.

6. Hee MR, Izatt JA, Swanson EA, Huang D, Schuman JS, Lin CP, et al. Optical coherence tomography of the human retina. Arch Ophthalmol. 1995; 113(3):325-32.

7. Hee MR, Puliafito CA, Duker JS, Reichel E, Coker JG, Wilkins JR, et al. Topography of diabetic macular edema with optical coherence tomography. Ophthalmology. 1998;105(2):360-70.

8. Goebel W, Kretzchmar-Gross T. Retinal thickness in diabetic retinopathy: a study using optical coherence tomography (OCT). Retina. 2002;22(6):759-67.

9. Browing DJ, McOwen MD, Bowen RM, Omarch TL. Comparison of the clinical diagnosis of diabetic macular edema with diagnosis by optical coherence tomography. Ophthalmology. 2004;111(4):712-15.

10. Otani T, Kishi S, Mauyama Y. Patterns of diabetic macular edema with optical coherence tomography. Am J Ophthalmol. 1999;127(6):688-93.

11. Cunha-Vaz JG. Pathophysiology of diabetic retinopathy. Br J Ophthalmol. 1978;62(6);351-5.

12. Brow JC, Solomon SD, Bressler SB, Schachat AP, DiBernardo C, Bressler NM. Detection of diabetic foveal edema: contact lens biomicroscopy compared with optical coherence tomography. Arch Ophthalmol. 2004;122(3):330-5.
13. Photocoagulation for diabetic macular edema: Early Treatment Diabetic Retinopathy Study Report no. 4. The Early Treatment Diabetic Retinopathy Study Research Group. Int Ophthalmol Clin. 1987;27(4):265-72.

14. Richer S. Exam room, chair side evaluation of retinal edema: improving accuracy and precision for identification of subclinical diabetic macular edema. Optometry. 2007;78(12):664-73.

15. Kang SW, Park CY, Ham D. The correlation between fluorescein angiographic and optical coherence tomography features in clinically significant diabetic macular edema. Am J Ophthalmol. 2004;137(2):313-22.

16. Massin P, Eric V, Haouchine B, Erginay A, Paques M, Gaudric A. Retinal thickness in healthy and diabetic subjects measured using optical coherence tomography mapping software. Eur J Ophthalmol. 2002;12(2):102-8.

17. Massin P, Vicaut E, Haouchine B, Erginay A, Paques M, Gaudric A. Reproducibility of retinal mapping using optical coherence tomography. Arch Ophthalmol. 2001;119(8):1135-42.

18. Hussain A, Hussain N, Nutheti R. Comparison of mean macular thickness using optical coherence tomography and visual acuity in diabetic retinopathy. Clin Exp Ophthalmol. 2005;33(3):240-5.

19. Diabetic retinopathy clinical research network. Relationship between optical coherence tomograghy-measured central retinal thickeness and visual acuity in diabetic macular edema. Ophthalmology. 2007;114:525-36.

\title{
11 Congresso de Oftalmologia da USP
}

\section{$10^{\circ}$ Congresso de Auxiliares de Oftalmologia da USP}

\section{8 a 30 novembro de 2008 \\ Centro de Convenções Rebouças - São Paulo - SP}

\author{
INFORMAÇÕES \\ Creative Solution \\ Tel.: (11) 5575-0254 \\ E-mail: info@congressousp.com.br \\ home-page: www.congressousp.com.br
}

